\title{
Sustainable tourism planning for the only coral reef in the Gulf of California: Cabo Pulmo national park
}

\author{
O. Arizpe \& M. Covarrubias \\ Universidad A. de Baja California Sur, Mexico
}

\begin{abstract}
The most northerly coral reef in the Eastern Pacific has supported commercial and sport fishing for almost a century. Research and assessments carried out since 1988 showed an increasing environmental impact of extractive actions resulting in a decline of coral cover and density of fish, mollusc and other marine populations, generating negative effects in the only coral reef in the Gulf of California. The growing importance of tourism activities, especially eco-tourism, as a source of employment and welfare creates the opportunity to shift from extractive actions to a sustainable tourism approach. The purpose of this study was to develop a rigorously planned management strategy to improve the health of the environment and the quality of life of the human population of Cabo Pulmo. The methods used included micro region zoning through a Geographical Information System and capacity of use evaluation, integrating the physical, biological, economical and social characteristics of the study area. Based on the evaluation of indexes of fragility, pressure, and vulnerability, 31 environmental units were proposed. The results showed that the predominant environmental policy would be sustainable management within $40 \%$ of the total area, restoration in $12 \%$, and a conservation and protection policy in $48 \%$. The sites with most human impact would need an environmental management policy, with the encouragement of sustainable tourism, while eliminating and further excluding any extreme use or high density traditional tourism. Many workshops and meetings have been organized to recommend management actions focusing on sustainable tourism and to discuss how to tailor specific features. After more than 15 years, a recent evaluation of this coralline system, now a National Park, demonstrated that the quality of life of the local inhabitants has improved, and
\end{abstract}


that there is a healthier ecosystem with coral recovery, and many sea turtles, sharks, other fish and invertebrates.

Keywords: sustainable tourism, management plan, coral reef.

\section{Introduction}

The Mexican state of Baja California Sur, located in the northwest of the country, has more than 3,000 km of coastline along the Pacific Ocean and Gulf of California, constituting almost $25 \%$ of the total Mexican shoreline. The wild, attractive, natural areas of Mexico, including stunning coastal and marine areas, great biodiversity, and the economic advantages of tourism, have stimulated the creation of many federal tourism projects, such as the huge Nautical Route of the Gulf of California [1]. However, many strategies are outdated and have generated unbalanced social, geographic and patchy development $[2,3]$. The beauty of coral reefs attracts an increasing number of scuba divers each year to many parts of the world. In general, submarine habitats and landscapes largely drive general tourism activities. Non-regulated development threatens the environment, making it necessary to search for strategies that help establish equilibrium between resource protection and regional development. Cabo Pulmo has the most northerly coral reef in the East Pacific and the only one to be found in the Gulf of California. For many years, fishing was a significant activity in Cabo Pulmo, which suddenly began to deplete fish stocks.

One portion of Bahia Cabo Pulmo and Bahia Los Frailes (an adjacent bay) have already been allocated as sites for hotels and bungalows. High impact tourism development has not yet begun, but it is imminent due to strong economic interests once the government completes surfacing the last kilometres of dirt road. For the reef, possible disturbances include increased turbidity, altered water circulation and modifications in patterns of sedimentation. These may damage or highly modify different biotic components and reef processes. Planning strategy needs to involve local people through a community-based approach, as recommended for most developing countries' reserves [4-6]. Research needs to address biological, socio-economic and archaeological aspects.

The growing importance of tourism, especially eco-tourism, as a source of employment and economic resources, creates the possibility of an alternative to extractive activities. However, this alternative needs careful planning, evaluation, control and continual adjustment throughout its development [7]. The planning process must include the analysis of physical, social and economic aspects. To achieve this goal, it is necessary to base evaluation on: 1) land capacity to withstand diverse activities, considering natural and socioeconomic interactions; and 2) potential environmental impact produced by the development of such activities [8]. This paper proposes a planning scheme for the sustainable tourism activities that take place on the coastal zone of the Cabo Pulmo Coral Reef, using ecological land use planning and use capacity methodology as tools of the environmental planning. 


\section{Study area}

Cabo Pulmo Coral Reef $\left(23^{\circ} 26^{\prime} \mathrm{N}, 109^{\circ} 25^{\prime} \mathrm{W}\right.$ and $\left.23^{\circ} 24^{\prime} \mathrm{N}, 109^{\circ} 24^{\prime} \mathrm{W}\right)$ supports the most extensive growth of coral in the Gulf of California $[9,10]$. The reef is situated in the Los Cabos region, one of the most important tourist development areas in Mexico. The Cabo Pulmo seafloor is gently sloping and presents four basalt bars, three of them largely covered in coral. The bars, or fingers, of the reef extend to a maximum depth of 60 feet, and minimum of 6 to 9 feet until exposure of coral heads during low tide. These submarine outcrops of this shallow reef support a diverse benthic community, consisting of a variety of algae, corals and other invertebrate species. The permanent human population of the region is composed of families of fishing tradition which have inhabited the area for many generations. There are also foreign residents now living in the bay.

\section{Methodology}

The main axis of the research methodology consisted of the zoning, evaluation and proposals for a plan of sustainable tourism activities for the determined environmental units, or micro regions, of the study area. The implementation of each of them had a clear purpose and a series of products, and each step was subject to the guidelines and mechanisms established by Mexican standards [7, $10,11]$. The description of the biotic, geophysical, social and economic components was compiled from all available data. This included publications, books and management programs, as well as statistical information from the National Statistic Geography and Informatics Institute and the Baja California Sur Government. Some of data was obtained direct from the field working with experts. Information was integrated on a Geographical Information System, using software ArcView 3.3 and an ASTER satellite image 1:50 000 resolution. The information used for zoning, and to obtain the environmental units for the terrestrial areas affecting the coral reef, was hydrology of the watershed, vegetation type, soil type and topography. For the projective phase, it was considered that the current rate of population growth and tourism would continue. After the first phase, the monthly meetings began with the local community and main stakeholders in the area. The aim of the meetings was to get the locals and main stakeholders of the national park involved in the planning process with their remarks, evaluation and their recommendations for the proposed sustainable tourism strategy. At this stage, a model [7] was applied to evaluate the composite indices of Pressure (IP), Fragility (IF) and Vulnerability (IV) [11-14]: the vulnerability index (IV) was the sum of IP and IF and was evaluated for each Environmental Unit (EU). This index spatially defines areas with greater demand for the natural resources of greatest vulnerability. Each EU was assigned an environmental policy according to the proposed categories in Article III of the Mexican Environmental Law [15]; Sustainable use, Conservation, Protection or Restoration. From these results, focusing on the specific characteristics of each site and EU, the sustainable tourism strategy was designed. This was then discussed with the locals, government authorities and 
tourism companies and adjustments made to develop final, specific models for official implementation in accordance with Mexican legislation.

\section{Results}

\subsection{Environmental components}

Cabo Pulmo is the oldest known coral reef in the American Pacific, with its age being estimated at 25,000 years [15], in contrast to 5000-5500 years for Panamanian reefs [16]. There are some paleontological remains of reef fauna at a Pleistocene marine terrace dated to $125 \mathrm{k} . \mathrm{a} . \pm 1000$ years. The reef biota is diverse and from four different bio geographic provinces: Panamic, Californian, Cortezian, and Indo-Pacific [17]. Cabo Pulmo reef was first described by the scientific community in the classic papers of Steinbeck and Ricketts [18], Squires [15] and Brusca and Thomson [9], who highlighted its importance as a special and unique ecosystem in the Gulf of California. The El Niño Southern Oscillation (ENSO) effect of 1982-1983, which almost destroyed the Pacific reefs of Galapagos, Costa Rica and Panama, was not apparent in Cabo Pulmo, perhaps demonstrating how it could be the oldest reef in the American Pacific.

The Cabo Pulmo region has a climate type BW, dry with sporadic rain in summer and winter. Average air temperature is $22.6^{\circ} \mathrm{C}$, with a maximum of $40^{\circ} \mathrm{C}$ and minimum of $16^{\circ} \mathrm{C}$. The main components of the flora are xeric scrublands, scrub and grassland [19]. The fauna is rich and diverse, with outstanding terrestrial mammals, seasonal arrival of marine and coastal birds, and of sea turtles of which some are considered threatened or in danger of extinction. All these animals alone could be seen as potential resources for nature tourism, for instance, their observation would assist their conservation and provide economic benefits for the local people

Cabo Pulmo reef has 10 of the 13 species of hermatypic corals reported in the Gulf [17, 20]. Pocillopora verrucosa is the dominant hermatypic coral, representing $33.6 \%$ relative to all other coral species (hermatypic and nonhermatypic), then $P$. meandrina with $22.6 \%$, Porites panamensis with $18.1 \%$, Pocillopora capitata with $11.1 \%$ and the other five species making up less than $10 \%$ each. In the offshore reef finger, the relative values of $P$. panamensis rise to $35 \%$ and $P$. verrucosa to $33.5 \%$. However, these figures have been slowly decreasing during the study period due to damage caused by boats anchoring on the coral heads. Total coral cover $>30 \%$ has been estimated in an area of approximately 350 ha. In the inshore finger, it is $41 \%, 30 \%$ in the middle, and $26 \%$ in the offshore finger reef.

\subsection{Human activities}

One small settlement is located in the area with a population of 150 people. Until 1991, the economics of Cabo Pulmo people was based mainly on artisanal fishing with the addition of $20 \%$ agriculture. However, nowadays tourism activities also play a part and consist of camping, hiking, mule treks and 
bicycling. These are sometimes related to activities that take place in the marine zone. Most of these activities have been developed by foreign people, mainly from The United States and Canada [21]. Camping is strongly correlated with kayaking and has a high season from October to May. The camping lacks regulation and the beaches have deteriorated as a result.

Tourism infrastructure consists of restaurants, one resort and scuba diving services. Along the coast of Bahía Cabo Pulmo, there are also archaeological remains belonging to Pericues tribes which inhabited the area during pre-colonial and Spaniard colony times. The resident human population comprises mainly fishing families that have lived there for generations and some foreigners. Currently, the amount of visitors is small, but it will certainly increase due to imminent completion of a paved road from the main highway.

From 1992 to 1993, studies were carried out in order to propose Cabo Pulmo reef as a Marine Park. Significant potential economic development of the region was highlighted. Several management goals and objectives for long-term management of area were recognised: (1) To preserve the coral reef, its components, associated habitats and biotic communities; (2) To preserve ecological processes and life support systems; (3) To maximise economic and social benefits from the area; (4) To promote conservation compatible uses; and (5) Promote environmental education between general public and research initiatives. It was proposed that goals could be reached through completion of the following objectives: (1) To implement monitoring and research programs to protect benthic communities; (2) To preserve the viability of the coral community by sustained environmental conditions to favour coral development; (3) To restore and preserve target populations of game and artisanal fish; (4) To promote economic alternatives for local residents; and (5) To implement an environmental education program at several levels, starting with the local residents. This proposal led to Cabo Pulmo reef being declared a protected zone by the Mexican government on June 5, 1995, under the category of National Marine Park [22]. This is the only officially protected coral reef on the Pacific coast of Mexico. Other important tourism cities near to coral growths, like Huatulco $\left(15^{\circ} \mathrm{N}\right)$ and Puerto Vallarta $\left(19^{\circ} \mathrm{N}\right)$, only have informal agreements with local dive shops and fishermen in order to avoid damage to, or extraction of, fauna and flora [20].

\subsection{Zoning}

With the analysis of satellite images from ASTER, site characterization and use of ArcView 3.3 software, four types of map were produced: topography, soils, vegetation types, and hydrology. These were further elaborated with georeferenced information of the five sub hydrological systems that are found in the study area, the five types of topography and three main vegetation types present in the municipality. From the integration of information, 31 environmental units (EU) were obtained, which are compatible with the scale of the work (1: 50000$)$ and the initial assessment of the suitability of the land. The main outcome of this phase was the analysis of suitability of land for tourism; not just high density or 
traditional tourism, but also on sustainable tourism. The greatest suitability was found to be along the coastal EU.

\subsection{Prospective}

Social and economic dynamics of the municipality of Los Cabos is reflected in the pressure index (IP), which is derived from the analysis of the population, current land use and the suitability for tourism and other economic activities. The areas with highest pressure are the ones adjacent to the coast and the sand dunes. Given the characteristics of the type of tourism in the area, the greatest pressure from tourism projects are located in the coastal units, while the EU without

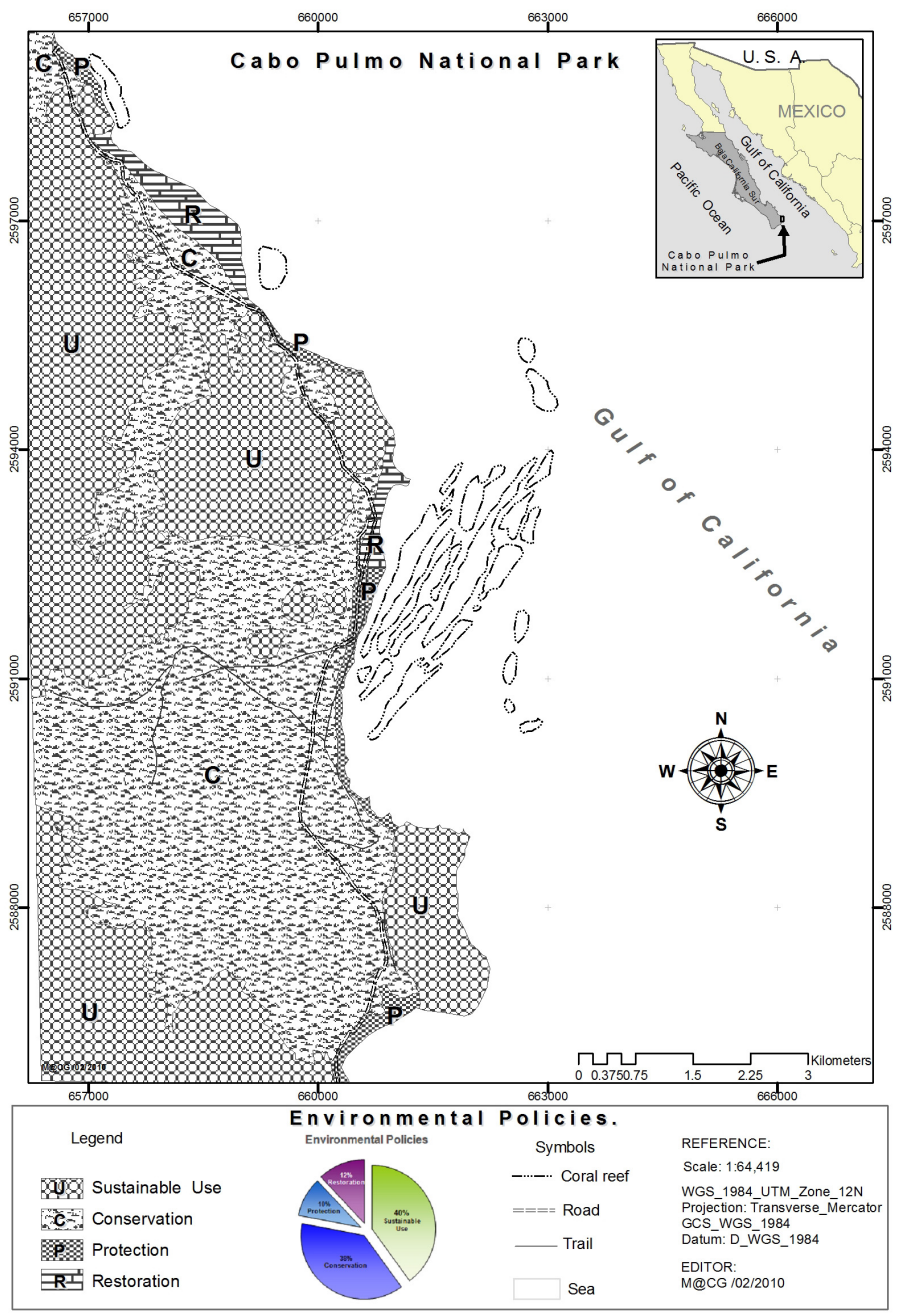

Figure 1: Environmental policies. 
coastline has fewer development projects. The evaluation of index of vulnerability (IV) for each EU served to assign one of four environmental policies (Sustainable Use, Restoration, Conservation or Protection), that further defined the guidelines reflecting the ecologically desirable state of the EU. Environmental strategies were derived that represent the specific objectives to achieve the ecological plans and a series of specific actions that define strategies for land use for each micro-region of Cabo Pulmo. Environmental policies are presented as follows: sustainable use $40 \%$, restoration $12 \%$, and conservation and protection $48 \%$ (Fig 1). In general, the strategic scenario is of conservation, which is a balance between preserving the natural environment while developing the activities of the productive sectors.

10 EUs were defined under the sustainable use policy with the ecological guidelines defined for this policy being to protect ecosystems and ecological processes; 14 EUs under the conservation policy; 5 under protection and 2 under the restoration policy. The ecological guidelines established for these environmental policies are a balance of sustainable development and productive activities, being compatible with the conservation of natural resources. The strategies developed include the identification of natural resources and their conservation status, and the study of areas suitable for the development of productive activities under a scheme of sustainability. In summary, the Cabo Pulmo region needs to develop various forms of alternative low-impact tourism. In addition, there could be the development of low and medium intensity tourism along the coastal strip depending on the characteristics of the area.

\subsection{Tourism activities strategy}

The main economic potential of Cabo Pulmo Park is of a recreational character, focused almost exclusively on aquatic activities such as snorkelling and scuba diving. Workshops and consult-meetings have taken place to discuss anything from initial plans to recommended management actions, permitted uses, prohibited activities and problems of each of the environmental units generated in the zoning process of Cabo Pulmo. The proposed scheme is shown in Figure 2 which integrates the environmental policies and each unit use capacity. Because of seasonal variations in weather conditions, the area allows the realization of more than one activity in several units. In general, this will mean no conflict for space or resource. The areas with a certain degree of modification present high capacity for all the tourism activities. The mountain areas have a medium capacity for camping, hiking and mule treks, while the suitability for bicycling is low. Units close to the coast line are considered recreational areas and camping, swimming and snorkelling can be done. In general, low impact activities are proposed, balancing the use of natural resources with continuous economic growth.

The marine areas have a great capacity for water sports, especially underwater tourism focusing on the coral reefs. Scuba diving is now very popular on Cabo Pulmo coral reefs for divers from all over the world. A strategic plan for scuba 


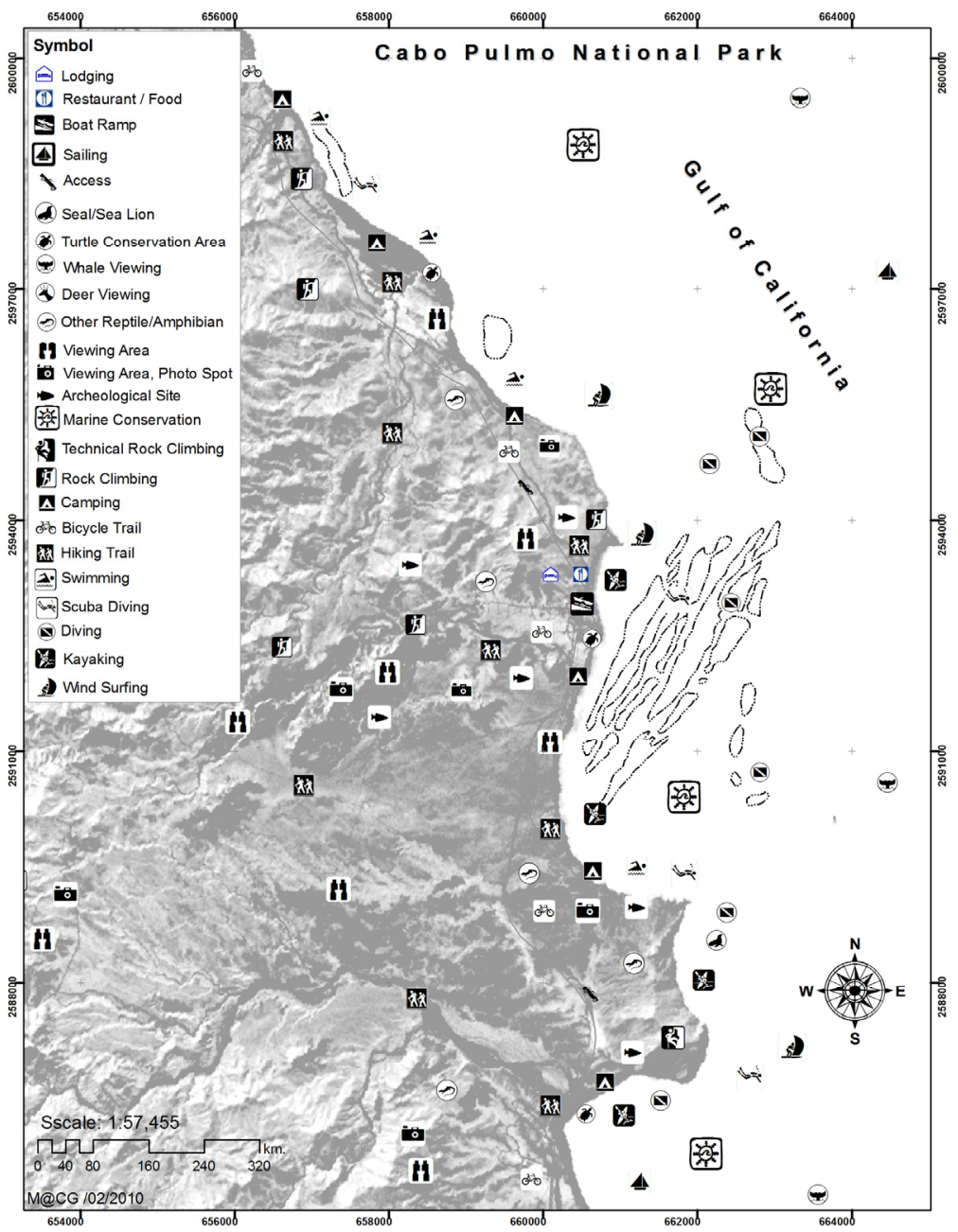

Figure 2: $\quad$ Sustainable tourism activities scheme.

diving on the coral reefs has been proposed with the design of a mooring buoys scheme, the forbidding of anchoring directly on reef areas and implementation of a plan of use for each specific site with strict regulations of the number and type of scuba divers. With this plan in effect, only the best qualified divers (dive masters) could use some of the most vulnerable sites, and the less qualified (open water divers) other selected reef sites with lower values of vulnerability. Considering this is the most important activity in the National Park, many workshops were developed to communicate the plan and to agree all the details to implement the plan. 


\section{Discussion and recommendations}

The creation of the protected area is just one of steps of management, but some regulations were expected to be started even before the design of the reserve. The first phase of the strategy, carried out by a research institution (University of Baja California Sur), government agencies and local residents, included the subsequent management programs: (1) the management plan elaboration, (2) an environmental education program for local residents and visitors, (3) the setting up of mooring buoy systems for recreation and scuba diving zones, (4) a monitoring program for environmental factors and benthic surveys, and (5) the financial assistance searching. This phase encompasses all immediate resourceuse conflicts and includes the establishment of programs of zoning, vigilance, law-enforcement, public education, defining of research priorities and financial assistance. Because all groups involved should participate in decision making, the major administrative structure in the reserve must be a council formed by representatives of local residents, tourism workers, educational and research centres and government agencies. However, the enforcement system should be based on local residents and tourism companies. This stage of the process is where most of the protected areas of Mexico have met their biggest problems, sometimes so difficult to overcome that management plans are almost useless or never applied. It is hoped that in Cabo Pulmo, with the collaboration of the local residents, government agencies and all sectors involved, the ideal of a wellmanaged, self-sustainable marine reserve will be achieved. However, at this time the management plan is still not implemented by the environmental authorities. Furthermore, many management actions need to be put into practice to diminish the negative impacts over the zone, and more scientific research is required as still little is known about the Cabo Pulmo Reef system.

Four activities take place in the terrestrial areas: hiking, camping, and trekking along marked trails and in anthropological sites. Due to the biological richness, there are other combined activities within the marine area, such as whale watching (blue and humpback whales), sea lions (Zalophus californianus) and bird watching. These activities, if well planned, can represent an important income to the local inhabitants. However, the site has on average only a medium capability to carry out many activities; this does not mean the prohibition of any activity, but it is necessary to regulate the current and future activities. It is important to emphasize that all the activities should be of low impact, otherwise there is a risk of the project failing and the fragmentation or destruction of the natural conditions.

According to the characteristics of the study area and the results of this paper, it is recommended to encourage minimum impact tourism with a sustainable focus, eliminating any extreme use. All activity must be regulated and recorded, including tourism services' lenders, all tourism activities, the places where they are realized, and the importance of each one. In addition, an investigation of potential resources for new tourism activities should be made. Moreover, it is indispensable that the Mexican Government defines, with integrated criteria, the extent of relevant sites in the Gulf of California for better characterization, 
diagnosis and management proposals, and encourages faster implementation. Everybody needs to be aware that stimulating traditional high impact tourism does not create higher employment levels. A recent evaluation after more than 15 years within this coralline system, now a National Park, has demonstrated good environmental conditions and a wealthier local population. The quality of life of the inhabitants has increased, within a healthier ecosystem, along with the recovery of coral, many sea turtles, sharks, other fish and invertebrate populations. The change in approach of the Cabo Pulmo population, from traditional fishing to sustainable tourism services, has created something more profitable than fishing, and the coralline ecosystem is recovering and getting better each year.

\section{References}

[1] FONATUR, Proyecto Mar de Cortés, http://www.fonatur.gob.mx.

[2] Gámez, A., Conference "El sector turismo en BCS", Junio 18, Universidad Mundial. La Paz, B.C.S. México, 2004

[3] Gámez, A. \& Montaño B., Diagnóstico Estratégico del Sector Turismo en Baja California Sur. En Diagnóstico Estratégico de Baja California Sur, Universidad Autónoma de Baja California Sur. La Paz, B.C.S. México. Pp. 277-311, 2003

[4] White, A.T., Marine parks and reserves: Management for coastal environments in Southeast Asia. Association of Southeast Asian Nations/United States Coastal Resources Management Project Education Series 2, 1988.

[5] White, A.T., The effect of community-managed marine reserves in the Philippines on their associated coral reef fish population, Asian Fisheries Science, 1(2) pp. 27-42, 1988.

[6] White, A.T. \& Palaganas V.P., Philipine Tubbataha Reef National Marine Park: Status, Management issues, and proposed plan. Environmental Conservation, 18(2), pp. 148-157, 1991

[7] Arizpe, O., Fermán J., Rivera R., Ramírez J. \& Rodríguez R., Evaluation and land use planning process of a high population growth rate municipality: Los Cabos, Mexico (Section 2), Environmental Economics and Investment Assessment II, eds. Aravossis, K., Brebbia, C.A. \& Gomez, N., WIT-Press, Great Britain, pp. 87-96, 2008.

[8] SEMARNAP, Ley General del Equilibrio Ecológico y Protección al Ambiente, México. Ediciones Delma, 1996.

[9] Brusca, R.C. \& Thomson, D.B., Pulmo reef: the only "coral reef" in the Gulf of California. Ciencias Marinas, 1, pp. 1: 37-53, 1975.

[10] Arizpe, O. El turismo como alternativa a la pesca en el manejo de un arrecife coralino. Caso Cabo Pulmo, Golfo de California (Chapter 42), eds. Rivera-Arriaga E., Villalobos-Zapata, G.J., Azuz-Adeath I. \& Rosado-May F., El Manejo Costero en México. Universidad Autónoma de Campeche, SEMARNAT, CETYS-Universidad, Universidad de Quintana Roo, pp. 573-588, 2004. 
[11] Espejel, I., León, C., Fermán, J.L., Bocco, G., Rosete, F., Graizbord, B., Castellanos, A., Arizpe, O. \& Rodríguez, G., Planeación del uso del suelo en la región costera del golfo de California y Pacífico Norte de México (Chapter 21). eds. Rivera-Arriaga E., Villalobos-Zapata, G.J., AzuzAdeath I. \& Rosado-May F., El Manejo Costero en México. Universidad Autónoma de Campeche, SEMARNAT, CETYS-Universidad, Universidad de Quintana Roo, pp. 321-240, 2004.

[12] OCDE, OCDE Core Set of Indicators for Environmental Performances Reviews, Environment Monographs, Paris, Frances, Organization for Economic Cooperation and development 39, 1993

[13] SEMARNAT-INE. Ecological ordinance del Mar de Cortés. Componente Social y Económico, http://www.ine.gob.mx

[14] SEMARNAP, Ley General del Equilibrio Ecológico y la Protección al Ambiente, México, pp. 244, 1997.

[15] Squires, D.F., Corals and coral reefs in the Gulf of California, Bull. Am. Mus. Nat. Hist. 118, pp. 371-431, 1959.

[16] Glynn, P.W. \& McIntyre, I.G., Growth rate and age of coral reefs on the Pacific coast of Panama. Prco. $3^{\text {rd }}$ International Symposium of Coral Reefs, Miami, 2:251-259.

[17] Reyes-Bonilla, H., 1993, Estructura de la comunidad, influencia de la depredación y biología poblacional de coral hermatípicos en el arrecife de Cabo Pulmo, Baja California Sur. Tesis de Maestría. Centro Interdisciplinario de Estudios Superiores de Ensenada. Ensenada Baja California. México, pp. 169, 1977.

[18] Steinbeck, J. \& Ricketts, E.F., Sea of Cortez, Viking Press, New York, U.S.A., pp. 598, 1941

[19] López-Espinosa de los Monteros, R., Propuesta de Ordenamiento de las Actividades de la Zona Marina de Loreto, B.C.S., México. Tesina de Especialidad, UABC, Ensenada, B. C., México, pp. 56, 1996.

[20] Reyes-Bonilla, H., The 1987 coral reef bleaching at Cabo Pulmo reef, Gulf of California, México. Bulletin of Marine Science, pp. 52, 832-837, 1993.

[21] FONATUR, Proyecto Mar de Cortés, http://www.fonatur.gob.mx.

[22] Diario Oficial de la Federación, Decreto por el que se declara área natural protegida con el carácter de Parque Marino Nacional, la zona conocida como Cabo Pulmo, ubicada frente a las costas del Municipio de Los Cabos, B.C.S., con una superficie de 7,111-01-00 hectáreas, Secretaría del Medio Ambiente, Recursos Naturales y Pesca, 51, pp. 3-5. June 6th, 1995. 